\title{
MTRR Gene
}

National Cancer Institute

\section{Source}

National Cancer Institute. MTRR Gene. NCI Thesaurus. Code C105126.

This gene plays a role in the metabolism of vitamins and amino acids. 